\title{
Micropropagation of Melissa officinalis L. through proliferation of axillary shoots
}

\author{
A. C. Tavares, M. C. Pimenta, and M. T. Gonçalves \\ Departamento de Botânica, Universidade de Coimbra, 3049 Coimbra Codex, Portugal \\ Received 29 March 1995/Revised version received 26 July 1995 - Communicated by G. C. Phillips
}

\begin{abstract}
Multiple shoots were differentiated in cotyledonary nodes of $10 \mathrm{~d}$ old seedlings of Melissa officinalis, cultured on MS medium supplemented with BAP $(0-4 \mathrm{mg} / 1)$. The production of shoots was further induced in subcultures of the original explant, after the first harvest of shoots (stump), using similar conditions. The highest average number of shoots in the two inoculations was obtained with $2 \mathrm{mg} / \mathrm{l}$ of BAP: 24 axillary shoots per explant, 7 in the first inoculation and 17 in the second one. The maximum elongation of shoots was achieved with $\mathrm{BAP}$ at $0.2 \mathrm{mg} / \mathrm{l}$, and higher concentrations of the hormone induced a decrease in their size. A range of BAP concentrations between $0.2-0.5 \mathrm{mg} / 1$ allowed the production of more shoots with a size suitable for rooting. Roots were induced in $30 \mathrm{~d}$ old shoots, transferred to MS medium individually supplemented with IBA or NAA $(0-4$ $\mathrm{mg} / \mathrm{l})$. Micropropagated plants were successfully transferred to soil.
\end{abstract}

Abbreviations: MS, Murashige and Skoog (1962) medium; BAP, 6-benzylaminopurine; IBA, indole-3-butyric acid; NAA, 1-naphthalene acetic acid; FAA, formalin-acetic acid-alcohol

\section{Introduction}

Melissa officinalis L. (Lamiaceae) is an aromatic plant with useful applications in medicine (infusion), cookery (condiment) and perfumery (aromatic constituents). Recently, the production and biotransformation of its secondary products through cell cultures has been attempted by Gbolade and Lockwood (1992). It has not been possible so far to obtain the plant characteristic flavour compounds using that technique of culture. Realizing the importance of this plant for different purposes, the application of methodologies that provide a large number of Melissa plantlets seems of interest. Shoot proliferation from apices or axillary buds to produce multiple shoots that are rooted is now recognized as a viable technique for plant propagation (Lane 1979; Morte and Honrubia 1992; Morte et al. 1992; Gulati and Jaiwal 1994). The aim of this work was to develop a reproducible protocol for the micropropagation of Melissa, using cotyledonary nodes as explant.

\section{Material and Methods}

Seeds of Melissa officinalis subsp. altissima collected in a natural wood (Vale de Canas) of Coimbra, Portugal, were surface sterilized with $7 \%(w / v)$ calcium hypochlorite and germinated axenically. Seedlings with the cotyledonary leaves expanded (about $10 \mathrm{~d}$ of germination) were cut at 2 $\mathrm{cm}$ below the insertion of the cotyledonary nodes (Fig. 1a) and cultured on MS medium, supplemented with $0-4 \mathrm{mg} / \mathrm{l}$ BAP. The culture media contained $3 \%(\mathrm{w} / \mathrm{v})$ sucrose, 100 $\mathrm{mg} / \mathrm{l}$ meso-inositol and $0.8 \%(\mathrm{w} / \mathrm{v})$ agar. The $\mathrm{pH}$ of all media was adjusted to 5.8 prior to autoclaving at $121^{\circ} \mathrm{C}$ for 20 minutes at $105 \mathrm{kPa}$. The cultures were maintained at $20-25^{\circ} \mathrm{C}$ and a light/dark cycle of $14 / 10 \mathrm{~h}$ under a photon irradiance of $120 \mu \mathrm{mol} \mathrm{m}^{-2} \mathrm{~s}^{-1}$. The stump (initial explant after the first harvest) was again inoculated in fresh media with the same hormonal composition. Shoots of the two inoculations were excised after 30 and $60 \mathrm{~d}$, respectively. Rooting was achieved in shoots longer than $5 \mathrm{~mm}$ using MS medium supplemented with $0-4 \mathrm{mg} / \mathrm{l}$ NAA or IBA. Plantlets with $1 \mathrm{~cm}$ of root length were transferred to basal medium for 1 month and then to small pots filled with garden soil and sand (1:1). The in vitro raised plants were hardened in a greenhouse and transplanted to the field.

All experiments were carried out 3 times. For each treatment a minimum of 20 (and as many as 100)

Correspondence to: A. C. Tavares 
replicates were used. Data were recorded after 30 and $60 \mathrm{~d}$ of incubation and the average number of shoots per explant were represented as mean values indicating the standard deviation (mean $\pm \mathrm{SD}$ ) (see Table 1 ).

For histological studies the explants were fixed in FAA and dehydrated through a graded ethanol-xylene series, followed by infiltration and embedding in paraffin. Serial sections 10-15 $\mu \mathrm{m}$ thick were cut and stained with safranin-fast green combination (Jensen 1962).

\section{Results and Discussion}

In a previous study (Gonçalves et al. 1989) we tested the action of different cytokinins for the production of shoots from the cotyledonary nodes of Melissa officinalis, and BAP proved to be the most effective. The present results indicate that BAP activated the multiplication of the axillary meristems of Melissa seedlings and that the regenerative capacity was maintained during the two subcultures of the explants.

At the time of inoculation only one axillary meristem of the explant (Fig. 1a) was evident in each cotyledonary node (Fig. 1b), as expected. In the basic medium we observed the incipient growth of the axillary shoots in $50 \%$ of the explants (Table 1, Fig. 1c). Multiple shoot initiation was observed in all BAP-supplemented media (Table 1) after $30 \mathrm{~d}$ in culture. In the first inoculation, BAP at $0.5 \mathrm{mg} / \mathrm{l}$ produced an average of 4 shoots per explant (Fig. 1d). Concentrations above $1 \mathrm{mg} / 1$ induced the production of 8 shoots per explant. With 4 $\mathrm{mg} / \mathrm{l}$ the average number of shoots/explant was 9
(Fig. 1e).Within $6 \mathrm{~d}$ of culture of the stump (initial explant after the first harvest), multiple axillary meristems were already developing in the cotyledonary nodes (Fig. 2a). The production of shoots was even greater during the second inoculation, as observed in Acacia nilotica (Dewan et al. 1992). This fact can be explained as a result of the release of apical dominance imposed by the apical shoot. If the apical shoot had been excised at the time of the first inoculation, the frequency of shoots may eventually be greater.

In this second inoculation concentrations of BAP at $0.5 \mathrm{mg} / \mathrm{l}$ or higher produced 7 shoots per explant (Table 1). The multiplication rate was higher with concentrations of BAP at $2 \mathrm{mg} / \mathrm{l}$ or higher (Fig. 2b), but it was concomitant with the reduction of shoot length, especially with $4 \mathrm{mg} / \mathrm{l}$ of BAP (Table 1, Fig. 2c). Moreover, with concentrations of BAP above $3 \mathrm{mg} / \mathrm{l}$ the formation of calli was frequent in both inoculations. The concentration of $0.2 \mathrm{mg} / \mathrm{l} \mathrm{BAP}$ induced a higher percentage of shoots suitable for rooting (longer than $5 \mathrm{~mm}$ ): $30 \%$ in the first inoculation and $37.9 \%$ in the second (Table 1 ).

Roots were successfully induced in shoots $0.5-2$ $\mathrm{cm}$ long when transferred to MS medium, alone or supplemented with IBA or NAA, within $10 \mathrm{~d}$. Both auxins promoted thizogenesis but also callus formation, so MS basal medium proved to be the most effective for root induction directly at the base of the shoots with no intermediate callus. In these conditions of culture $90 \%$ of the explants

Table 1 - Effect of BAP on multiple shoot formation from cotyledonary node explants of Melissa officinalis.

\begin{tabular}{|c|c|c|c|c|c|c|}
\hline \multirow{2}{*}{$\begin{array}{l}\text { BAP } \\
(\mathrm{mg} / \mathrm{l})\end{array}$} & \multicolumn{3}{|c|}{ 1st harvest (after $30 \mathrm{~d}$ ) } & \multicolumn{3}{|c|}{ 2nd harvest (after another $30 \mathrm{~d}$ ) } \\
\hline & $\mathrm{N}^{\circ}$ expl. & $\begin{array}{c}\text { average number } \\
\text { shoots/explant } \pm \mathrm{SD}\end{array}$ & $\begin{array}{c}\% \text { shoots }> \\
5 \mathrm{~mm} \\
\end{array}$ & $\mathrm{~N}^{\circ}$ expl. & $\begin{array}{c}\text { average number } \\
\text { shoots/explant } \pm S D\end{array}$ & $\begin{array}{c}\% \text { shoots }> \\
5 \mathrm{~mm}\end{array}$ \\
\hline 0.0 & 90 & $1.1 \pm 0.6$ & 24.5 & 17 & $2.0 \pm 0.7$ & 2.4 \\
\hline 0.2 & 105 & $2.5 \pm 0.8$ & 30 & 32 & $2.2 \pm 0.5$ & 37.9 \\
\hline 0.5 & 99 & $4.0 \pm 0.6$ & 17.4 & 46 & $7.0 \pm 2.4$ & 11.1 \\
\hline 1.0 & 95 & $8.4 \pm 2.7$ & 3.1 & 56 & $9.7 \pm 2.9$ & 4.6 \\
\hline 2.0 & 102 & $7.3 \pm 3.1$ & 0 & 50 & $17.0 \pm 2.8$ & 12 \\
\hline 3.0 & 87 & $7.9 \pm 0.9$ & 0.14 & 46 & $13.3 \pm 1.1$ & 5.7 \\
\hline 4.0 & 81 & $9.0 \pm 3.8$ & 0 & 59 & $11.1 \pm 2.7$ & 1.1 \\
\hline
\end{tabular}




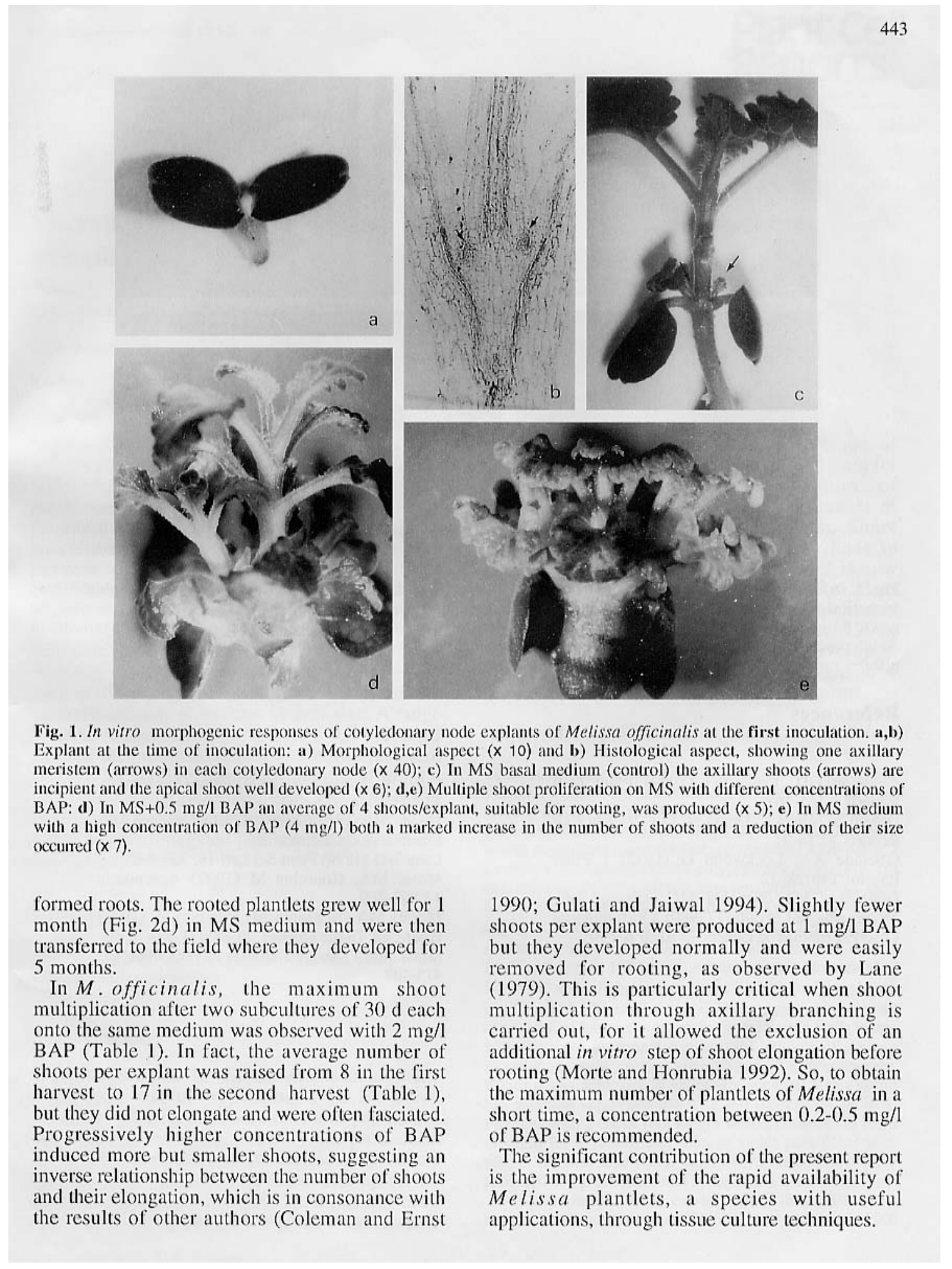


444
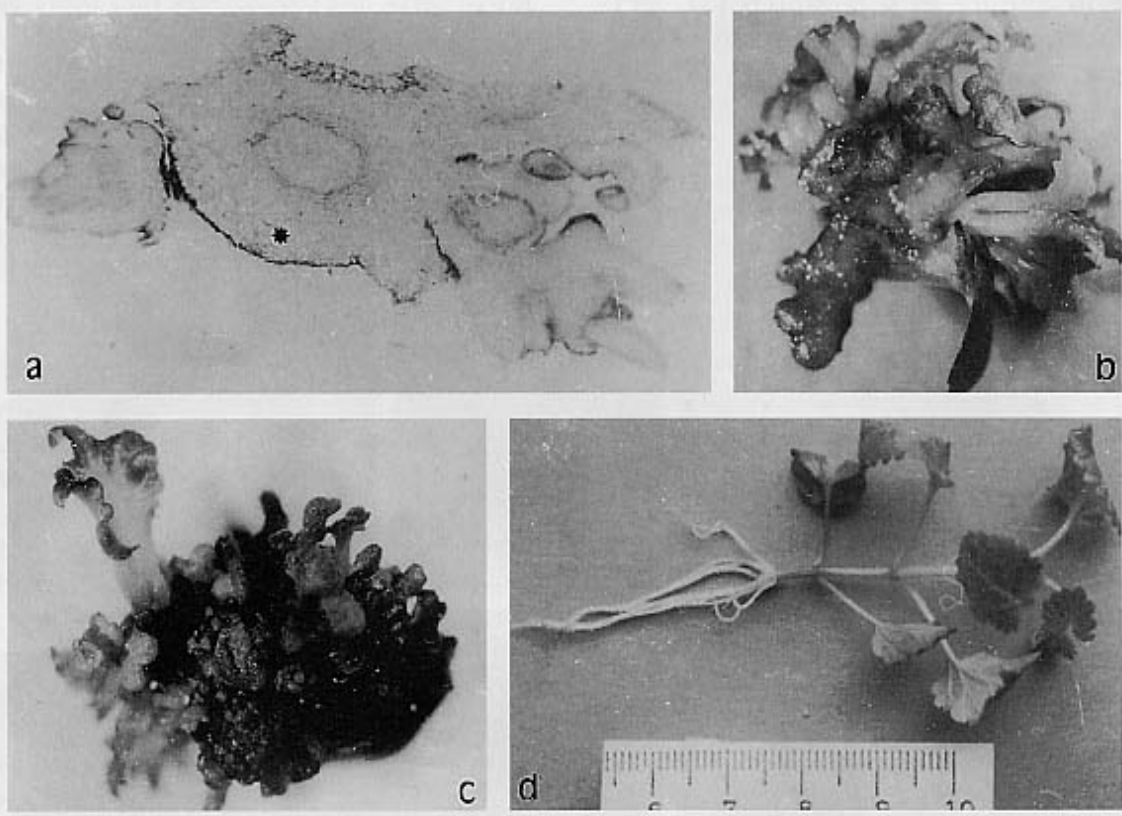

Fig. 2. In vitro morphogenic response of the Melissa officinalis stump at the second inoculation. a,b,c) Multiple shoot formation on MS with BAP: a) Longitudinal section of the stump $\left(^{*}\right)$ after $6 \mathrm{~d}$ of culture on MS+1 $\mathrm{mg} / \mathrm{BAP}$, showing the newly formed buds $(x 20)$; b) In MS $+2 \mathrm{mg} / \mathrm{l} \mathrm{BAP}$ an average of 17 shoots/explant was produced $(x 5)$; c) In the presence of a high concentration of BAP $(4 \mathrm{mg} / \mathrm{l})$, only a few of the numerous shoots were suilable for rooting $(x 5)$; $d)$ In vitro rooted plantlet 1 month after transfer to basal medium (scale in $\mathrm{cm}$ ).

\section{References}

Coleman GD, Ernst SG (1990) Plant Cell Reports 9:165-167

Dewan A, Nanda K, Gupta SC (1992) Plant Cell Reports 12:18-21

Gbolade AA, Lockwood G (1992) J Plant Physiol 140:28-32

Gonçalves MT, Pimenta MC, Tavares AC, Montezuma de Carvalho J (1989) XXIV Jomadas Luso-Espanholas de Genética, Abstr p P70
Gulati A, Jaiwal PW (1994) Plant Cell Reports 13:523-5276

Jensen WA (1962) Botanical histochemistry. WH Freeman \& Co, London

Lane WD (1979) Plant Sci Lett 16: 337-342

Morte MA, Honrubia M (1992) Agronomie 12:807-809

Morte, MA, Honrubia M, Piqueres A (1992)

Plant Cell Tissue Organ Cult 28:231-233

Murashige T, Skoog F (1962) Physiol Plant 15: 473-497 